\title{
Michael FIEDROWICZ, Theologie der Kirchenväter. Grundlagen frühchrist- licher Glaubensreflexion, Freiburg - Basel - Wien 2007, Herder, ss. 448.
}

Michael Fiedrowicz w swojej najnowszej książce Theologie der Kirchenväter. Grundlagen frühchristlicher Glaubensreflexion podejmuje temat formowania się wczesnochrześcijańskich dogmatów i ukazuje w ten sposób kształtowanie się i rozwój teologii w jej historycznym wymiarze. Ukazanie myśli wczesnochrześcijańskich autorów, ich nauczania w Kościele, w niezmiernie trudnych przecież warunkach, jest cennym wkładem do poznania teologicznej metody Ojców Kościoła i pisarzy starożytności chrześcijańskiej, dzięki której posiadamy wgląd w bogaty, pasjonujący i inspirujący nas ciągle świat pierwszych wieków chrześcijaństwa.

Obszerna, bo licząca 448 stron monografia M. Fiedrowicza Theologie der Kirchenväter. Grundlagen frühchristlicher Glaubensreflexion, składa się ze wstępu, w którym Autor uzasadnia konieczność i celowość podjęcia tematu teologii Ojców Kościoła, z dziewięciu części oznaczonych literami od A do I oraz z dodatku zawierającego: wykorzystaną literaturę, indeks osób, rzeczy i pojęć. Poszczególne części natomiast zawierają punkty rozwinięte w odpowiednich podpunktach.

Autor postawił sobie ambitny cel, aby ukazać historię kształtowania się teologii w oparciu o okres patrystyczny. Słusznie bowiem wychodzi z założenia, że pisma Ojców Kościoła i pisarzy starożytności chrześcijańskiej, dokumenty soborowe, teksty liturgiczne oraz różnego rodzaju badania archeologiczne pomagają nie tylko poznać czasy pierwotnego Kościoła, ale przede wszystkim stanowiły w starożytności najważniejsze źródła do rozwoju dogmatów chrześcijańskich.

Już we wstępie swojej książki Autor zadaje sobie i czytelnikowi uzasadnione oraz ważne pytania dotyczące wiary i teologii. Między innymi: w jaki sposób poznanie prowadzi człowieka do wiary przekazanej przez pośrednictwo Apostołów? Kto zagwarantował autentyczną interpretację przekazanej Tradycji w formie ustnej lub pisemnej? Jaką rolę odgrywa rozum ludzki w poznaniu tajemnicy wiary? Czy można mówić z jednej strony o możliwościach, z drugiej zaś o granicach ludzkiego poznania? Jakie sytuacje przyczyniły się do pogłębienia refleksji teologicznej? W jaki sposób rozwijały się kryteria refleksji nad tajemnicą wiary? Autor nie pozostaje jednak wyłącznie na płaszczyźnie stawianych pytań, ale w sposób kompetentny i profesjonalny odpowiada na nie w kolejnych częściach swojej monografii. Posługuje się przy tym wspomnianymi źródłami historycznymi, ponieważ, jak sam słusznie zaznacza, są one potrzebne do zbadania całego procesu rozwoju teologii i miejsca wiary w myśli teologicznej. Źródła te pomagają i pozwalają dojść do prawdy, do wiary, do wypracowania nauki zwanej teologią. Podstawowym zatem celem przedstawionej monografii jest odpowiedź na pytanie: jaki jest wkład Ojców 
Kościoła i pisarzy starożytności chrześcijańskiej w rozwój teologii i myśli wczesnochrześcijańskiej.

Pierwsza część obszernego opracowania prof. M. Fiedrowicza dotyczy uzasadnienia prawowierności refleksji wiary w oparciu o kontrowersję z gnostykami, tak często podejmowaną w starożytności chrześcijańskiej przez Ojców Kościoła i pisarzy tej epoki. Autor wykorzystuje w tym względzie zwłaszcza myśl teologiczną Klemensa Aleksandryjskiego (II w.), Orygenesa (III w.), św. Hilarego z Poitiers (IV w.) oraz św. Augustyna (V w.). Jeden z rozdziałów tej części opracowania poświęcony został ukazaniu polemiki, jaką podejmował Klemens Aleksandryjski i św. Ireneusz z gnostykami. To zaś prowadzi Autora do zaprezentowania początków teologii, która miała już charakter wyraźnie naukowy dzięki Orygenesowi, później zaś św. Hilaremu z Poitiers oraz św. Augustynowi.

W drugiej części swojej książki, Autor omawia to wszystko, co związane jest z Tradycją rozumianą jako przekaz nieskażonej wiary od czasów apostolskich. Problem ten ukazuje także w kontekście doktryny gnostyków, którzy rozumieli nie tylko w inny sposób samo pojęcie „Tradycji” w Kościele, ale także uznawali siebie za wyłącznych jej spadkobierców. M. Fiedrowicz wychodzi zatem od samego pojęcia „Tradycji” w czasach apostolskich, następnie w oparciu o świadectwa i wypowiedzi św. Ireneusza z Lyonu oraz Tertuliana, pokazuje błędy gnostyków, wreszcie przedstawia wzajemny stosunek tradycji ustnej i pisanej, jako prawdziwie apostolskiej i przechowywanej w Kościele.

Kolejna, trzecia część książki, stanowi wyjaśnienie szerokiego tematu, jakim jest Pismo Święte i jego rola w podejmowanej przez Ojców Kościoła refleksji nad wiarą. Znaczną część swojego wywodu poświęca Autor na omówienie hermeneutyki biblijnej, a zwłaszcza ukazuje metody interpretacji Pisma Świętego, jakimi posługiwali się Ojcowie Kościoła. Chodzi tutaj przede wszystkim o typologię i alegorię biblijną, szeroko stosowane w środowisku wschodnim i zachodnim Kościoła.

Czwarta część książki poświęcona jest temu, co w starożytności nazywano początkowo regula fidei, później zaś wyznaniem wiary. Kształtowanie się Credo posiada długą historię i należy je odczytywać w kontekście biblijnych, chrzcielnych i indywidualnych wyznań wiary, które zostały w pewien sposób usystematyzowane na Soborze Nicejskim (325) i Konstantynopolitańskim I (381).

Ważnym problemem, który Autor książki ukazuje w kolejnej, piątej części, jest stosunek lex orandi do lex credendi. Znalazło to swój szczególny wyraz w liturgii, która w Kościele kształtowała się przez wieki, jej zaś zadaniem było pomóc człowiekowi uwierzyć i pogłębić otrzymany dar wiary.

Część szósta książki związana jest ściśle z przedstawieniem argumentacji stosowanej przez Ojców Kościoła dla wyrażenia poprawnej teologii. Autor ukazuje ten aspekt także w kontekście istniejących sporów dogmatycznych i chrystologicznych. Chodzi tutaj zwłaszcza o kontrowersję podjętą przez św. Atanazego z arianami, czy też św. Augustyna z donatystami. 
Siódma część książki dotyczy ogólnie soborów powszechnych, ze szczególnym jednak uwzględnieniem Nicejskiego, który przez wielu teologów uważany był w pierwszych wiekach za najważniejszy, w którym nie wolno niczego zmieniać i poprawiać.

Kolejna, ósma część, związana jest z rozwojem teologii, jaki nastąpił od IV wieku. Autor książki powraca do problematyki soborów powszechnych: zwłaszcza Konstantynopolitańskiego I, Efeskiego i Chalcedońskiego, aby ukazać pewien postęp w rozwoju teologii, jaki dokonał się po Nicei, nawet mimo pewnej opozycji co do zasadności zwoływania wspomnianych soborów. Przyczyniły się one bowiem, co podkreśla Autor książki, do umocnienia i uaktualnienia wiary nicejskiej.

Ostatnia, dziewiąta część książki poświęcona jest tematowi ortodoksji i herezji w Kościele. Autor szeroko omawia cechy prawdziwości wiary i potrzebę jej obrony w kontekście błędów, które rodziły się w Kościele od początkowych już chwil jego zakładania. Samo zaś pojawianie się herezji we wspólnocie Kościoła świadczyło o tym, że istniały i ścierały się różne poglądy. Można powiedzieć, że dzięki błędom w interpretacji niektórych prawd teologicznych, wypracowana została, niekiedy z wielkim trudem, poprawna teologia.

Przedstawiona powyżej ogólna charakterystyka książki M. Fiedrowicza Theologie der Kirchenväter. Grundlagen frühchristlicher Glaubensreflexion, pozwala na stwierdzenie, iż stanowi ona ważne i cenne opracowanie dotyczące teologii Ojców Kościoła. Jest to bowiem temat, który należy ustawicznie podejmować, gdyż starożytna myśl chrześcijańska ciągle jeszcze nie została całkowicie przybliżona, właściwie odczytana i przedstawiona. Autor książki - prof. Fakultetu Teologicznego w Trier, należy do osób, które doskonale znają przedmiot swoich badań. Jest on nie tylko wykładowcą i znawcą historii Kościoła starożytnego, patrologii i archeologii chrześcijańskiej, lecz także autorem wielu monografii, opracowań, przekładów, artykułów, recenzji i haseł do różnego rodzaju encyklopedii i leksykonów ze wspomnianej dziedziny. Tym bardziej cieszy fakt pojawienia się nowej jego monografii, tym razem poświęconej teologii Ojców Kościoła, rozpatrywanej w kontekście wczesnochrześcijańskiej refleksji nad tajemnicą wiary, przekazanej Kościołowi przez pośrednictwo i działalność ewangelizacyjną Apostołów. Z całą pewnością książka Theologie der Kirchenväter. Grundlagen frühchristlicher Glaubensreflexion stanowi przyczynek do lepszego poznania samych Ojców Kościoła i pisarzy starożytności chrześcijańskiej, a także rozlicznych problemów, z jakimi borykali się na co dzień w nauczaniu i przekazywaniu prawd wiary. Autor ukazuje cały mechanizm ich działania w trudnych niekiedy kontrowersjach, podejmowanych zwłaszcza z gnostykami, arianami czy też donatystami, nie mówiąc o apolinaryzmie i nestorianizmie. Cenne w tym opracowaniu jest z pewnością dotarcie do wypowiedzi wielu Ojców Kościoła i pisarzy starożytności chrześcijańskiej, i odczytanie ich myśli w szerokim kontekście zarówno 
filozoficznym, jak też biblijnym i społecznym. Autor usiłuje dzięki temu dotrzeć do podstaw wczesnochrześcijańskiej refleksji nad skarbem wiary, jaki otrzymaliśmy od samego Chrystusa poprzez Apostołów i bogatą Tradycję Kościoła.

Należy jeszcze dodać, że Autor podkreśla w swoim opracowaniu, iż teologia patrystyczna, oparta i wywodząca się od Ojców Kościoła i pisarzy starożytności chrześcijańskiej, nie przedstawia ich prywatnych myśli i poglądów, ale są one ściśle związane z tym, co otrzymał Kościół od Apostołów, czego nauczał i w co wierzyli wierni. Dlatego też tak wielka jest zasługa tych pierwszych świadków wiary i zarazem twórców teologii w powstanie i rozwój dogmatów oraz ważnej i niekiedy niedocenianej dziedziny nauki zwanej teologią.

Chciałbym także wskazać na pewne punkty, których zabrakło mi w książce prof. M. Fiedrowicza. Jest to bez wątpienia bardzo poważne i dojrzałe potraktowanie tematu teologii Ojców Kościoła. Warto byłoby zatem podać w bibliografii pełen spis wykorzystanych wypowiedzi Ojców Kościoła. Zdaję sobie sprawę z tego, że jest ich bardzo wiele, co można zauważyć w sporządzonym przy końcu indeksie (ss. 443-445), ale przy tego rodzaju monografii zabrakło mi tego punktu. Wypowiedzi Ojców Kościoła i pisarzy starożytności chrześcijańskiej stanowią przecież teksty źródłowe, na których w pełni opiera się Autor opracowania przy przedstawianiu tematu zapowiedzianego w jego tytule.

Myślę, że warto by również poszczególne części książki, których jest w sumie dziewięć, zaopatrzyć w krótkie podsumowania tematu. Autor czyni to w tekście, ale byłoby chyba celowe dodać w każdej z części tego rodzaju osobny punkt, aby czytelnik mógł w tak bogatym materiale źródłowym i analitycznym, odnaleźć podstawowe przesłanie i wnioski, do których dochodzi Autor książki po analizie tekstów źródłowych.

Zabrakło mi także krótkiego zakończenia wszystkich wywodów Autora, które stanowiłoby podsumowanie całości opracowania i wskazywało na ewentualne możliwości oraz drogi do pogłębienia i poszerzenia podjętego tematu, który przecież nie należy do marginalnych, ale niezmiernie istotnych w szeroko rozumianej teologii.

Wymienione sugestie w niczym oczywiście nie pomniejszają wartości przedstawionej monografii M. Fiedrowicza Theologie der Kirchenväter. Grundlagen frühchristlicher Glaubensreflexion. Stanowią one jedynie głos czytelnika i mogą pomóc w jeszcze lepszym rozeznaniu się w temacie; co więcej, całość, w moim przekonaniu, otrzymałaby dopełnienie i ubogaciła się w ten sposób o potrzebne nowe elementy tego ciekawego i pożytecznego opracowania.

Ks. Bogdan Czyżewski - Gniezno, UAM 